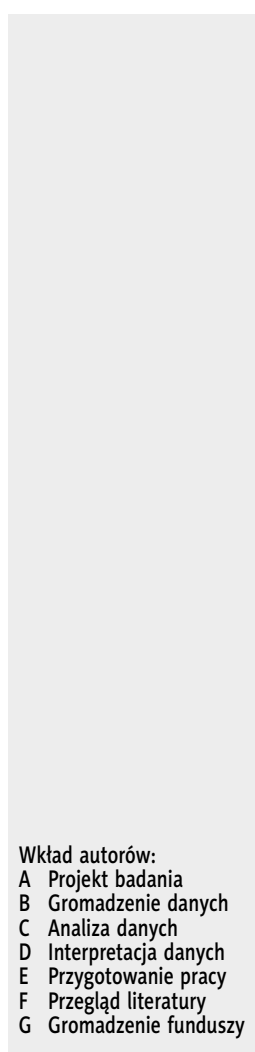

\title{
Leczenie zaburzeń słuchu z użyciem implantów ślimakowych i pniowych w 2014 roku - diagnostyka , potrzeby, dostępność w różnych regionach Polski
}

\section{Hearing loss treatment with cochlear or brainstem implants in 2014 - diagnostic, needs, availability in various regions of Poland}

\author{
Henryk Skarżyński ${ }^{1 B C D}$, Elżbieta Włodarczyk ${ }^{1 C D}$, Aleksandra Kowalczuk ${ }^{1,3 C D E F}$, \\ Bartosz Stawowski ${ }^{2 B C}$, Piotr H. Skarżyński ${ }^{1,3,4,5 B C D E}$ \\ ${ }^{1}$ Instytut Fizjologii i Patologii Słuchu, Klinika Oto-Ryno-Laryngochirurgii, Warszawa \\ ${ }^{2}$ Ministerstwo Zdrowia, Departament Analiz i Strategii, Warszawa \\ ${ }^{3}$ Instytut Fizjologii i Patologii Słuchu, Światowe Centrum Słuchu, Zakład Teleaudiologii \\ i Badań Przesiewowych, Kajetany/Warszawa \\ ${ }^{4}$ Warszawski Uniwersytet Medyczny, II Wydział Lekarski, Zakład Niewydolności Serca \\ i Rehabilitacji Kardiologicznej, Warszawa \\ ${ }^{5}$ Instytut Narządów Zmysłów, Kajetany
}

\begin{abstract}
Streszczenie
Wstęp: Systemy implantów ślimakowych są skuteczną i sprawdzoną metodą leczenia znacznych i głębokich niedosłuchów u pacjentów w każdym wieku, stosowaną w wielu ośrodkach medycznych w Polsce i na świecie. Obecnie wśród pacjentów korzystających $\mathrm{z}$ tego rozwiązania znajdują się osoby z różnego stopnia resztkami słuchowymi, użytkownicy bilateralni, pacjenci z jednostronną głuchotą bądź asymetrycznym niedosłuchem.

Materiały i metody: Materiał do pracy stanowiły dane pochodzące z map potrzeb zdrowotnych w Polsce w zakresie chorób nosa, zatok przynosowych, ucha, gardła i krtani. Dane dotyczyły hospitalizacji związanych z implantacją ślimakową w 2014 roku. Dzięki zestawieniom w nich zawartym możliwe jest całościowe spojrzenie na system opieki zdrowotnej w zakresie leczenia zaburzeń słuchu przy zastosowaniu implantów ślimakowych i pniowych w Polsce, a co za tym idzie - wyciągnięcie pewnych wniosków oraz zwrócenie uwagi na problemy i potrzeby tej grupy pacjentów.

Wyniki: $Z$ danych zawartych w mapach potrzeb zdrowotnych wynika, że największa liczba hospitalizacji związanych z leczeniem zaburzeń słuchu z użyciem implantów ślimakowych bądź pniowych dotyczy dzieci w wieku 1-9 lat oraz osób w wieku $\geq 60$ lat. Na pierwszym miejscu wśród placówek medycznych, w których sprawozdano najwięcej tego typu hospitalizacji, znajduje się Instytut Fizjologii i Patologii Słuchu w Kajetanach (385 hospitalizacji w 2014 roku).

Wnioski: Wraz ze zmianą kryteriów kwalifikujących do wszczepienia implantu ślimakowego bądź pniowego wzrasta liczba hospitalizacji związanych z leczeniem zaburzeń słuchu z użyciem tych systemów. Proces leczniczo-rehabilitacyjny w przypadku tej grupy pacjentów jest złożony i wymaga zaangażowania wielu specjalistów (doświadczonych lekarzy, inżynierów medycznych, psychologów, logopedów, surdopedagogów) w celu osiągnięcia jak najlepszych korzyści słuchowych. Dodatkowo, w związku z rosnącą liczbą użytkowników implantów ślimakowych bądź pniowych, wzrasta także zapotrzebowanie na wymianę części zewnętrznej systemu, czyli procesora mowy, po upływie okresu gwarancyjnego. Obecnie czas oczekiwania na wyminę sprzętu jest długi, a w skrajnych przypadkach wiąże się to nawet z zaprzestaniem korzystania z implantu oraz utratą wypracowanych dotychczas korzyści słuchowych. Słowa kluczowe: implanty ślimakowe • implanty pniowe • dostępność w Polsce
\end{abstract}

Adres autora: Aleksandra Kowalczuk, Zakład Teleaudiologii i Badań Przesiewowych, Instytut Fizjologii i Patologii Słuchu, ul. Mokra 17, Kajetany, 05-830 Nadarzyn, e-mail: a.kowalczuk@ifps.org.pl 


\section{Abstract}

Introduction: Cochlear implant systems are an effective and proven method to treat severe and profound hearing loss in patients of all ages, used in many medical centers in Poland and in the world. Currently among patients using this solution there are people with residual hearing, bilateral users, people with single sided deafness or asymmetric hearing loss.

Materials and methods: The data included in this work came from documents called 'maps of health needs' in Poland in the field of diseases of the nose, paranasal sinuses, ear, throat and larynx. Data related to hospitalization related to cochlear implantation in 2014. Thanks to the lists included in them, it is possible to have a holistic view of the health care system in the treatment of hearing disorders using cochlear and brainstem implants in Poland, and thus draw some conclusions and attention to the problems and needs of this group of patients.

Results: The data included in the maps of health needs show that the largest number of hospitalizations related to the treatment of hearing disorders with the use of cochlear or brainstem implants refers to children aged 1-9 years and persons $\geq 60$ years. The Institute of Physiology and Pathology of Hearing in Kajetany is the first place among the medical centers in which the highest number of such hospitalizations was reported (385 hospitalizations in 2014).

Conclusions: Along with the change of qualification criteria for cochlear or brainstem implantations, the number of hospitalizations related to the treatment of hearing disorders using those systems increase. The treatment and rehabilitation process for this group of patients is complex and requires the involvement of many specialists (experienced doctors, medical engineers, psychologists, speech therapists, teachers of the deaf) in order to achieve the best possible hearing benefits. In addition, due to the growing number of users of cochlear or brainstem implants, the need to replace the external part of the system, i.e. the speech processor, increases after the warranty period. Currently, the waiting time for the replacement of equipment is long, and in extreme cases it is even related to the discontinuation of the use of the implant and the loss of the auditory benefits earned so far.

Keywords: cochlear implants • brainstem implants • accessibility in Poland

Wykaz skrótów:

\begin{tabular}{|c|c|c|}
\hline Skrót & Rozwinięcie w języku angielskim & Znaczenie w języku polskim \\
\hline$A B I$ & auditory brainstem implant & implant pniowy \\
\hline $\mathrm{Cl}$ & cochlear implant & implant ślimakowy \\
\hline EABR & electrically evoked auditory brainstem response & pomiar elektrycznie wywołanych odpowiedzi z pnia mózgu \\
\hline ECAP & $\begin{array}{l}\text { electrically evoked compound action potential of } \\
\text { the auditory nerve }\end{array}$ & $\begin{array}{l}\text { pomiar elektrycznie wywołanego potencjału czynnościowego } \\
\text { z nerwu słuchowego }\end{array}$ \\
\hline ESRT & electrically evoked stapedius responses thresholds & $\begin{array}{l}\text { pomiar elektrycznie wywołanego odruchu z mięśnia } \\
\text { strzemiączkowego }\end{array}$ \\
\hline FDA & Food and Drug Administration & Agencja Żywności i Leków \\
\hline ICD-9 & $\begin{array}{l}\text { International Classification System for Surgical, } \\
\text { Diagnostic and Therapeutic Procedures }\end{array}$ & Międzynarodowa Klasyfikacja Procedur Medycznych \\
\hline ICD-10 & $\begin{array}{c}\text { International Statistical Classification of Diseases } \\
\text { and Related Health Problems }\end{array}$ & $\begin{array}{l}\text { Międzynarodowa Statystyczna Klasyfikacja Chorób } \\
\text { i Problemów Zdrowotnych }\end{array}$ \\
\hline ICF & $\begin{array}{c}\text { International Classification of Functioning, } \\
\text { Disability and Health }\end{array}$ & $\begin{array}{c}\text { Międzynarodowa Klasyfikacja Funkcjonowania, } \\
\text { Niepełnosprawności i Zdrowia }\end{array}$ \\
\hline MPZ & - & mapy potrzeb zdrowotnych \\
\hline NHNES & National Health and Nutrition Examination Survey & - \\
\hline PDT & Partial Deafness Treatment & leczenie częściowej głuchoty \\
\hline PDT-EC & PDT-Electric Complementation & $\begin{array}{l}\text { Metoda leczenia częściowej głuchoty za pomocą implantu } \\
\text { ślimakowego polegająca na elektrycznym dopetnieniu istniejącego } \\
\text { dobrego słuchu na niskich częstotliwościach }\end{array}$ \\
\hline PDT-EAS & PDT-Electroacoustic Stimulation & $\begin{array}{c}\text { Metoda leczenia częściowej głuchoty za pomoca implantu } \\
\text { ślimakowego polegająca na jednoczasowej stymulacji } \\
\text { elektroakustycznej }\end{array}$ \\
\hline PDT-ENS & PDT-Electro-Natural Stimulation & $\begin{array}{c}\text { Metoda leczenia częściowej głuchoty za pomocą implantu } \\
\text { ślimakowego polegająca na połączeniu zachowanego } \\
\text { w uchu implantowanym słuchu akustycznego dla niskich } \\
\text { i średnich częstotliwości ze stymulacją elektryczną w zakresie } \\
\text { wysokich częstotliwości }\end{array}$ \\
\hline PDT-ES & PDT-Electric Stimulation & $\begin{array}{c}\text { Metoda leczenia częściowej głuchoty za pomocą implantu } \\
\text { ślimakowego polegająca na wyłącznym zastosowaniu } \\
\text { stymulacji elektrycznej }\end{array}$ \\
\hline
\end{tabular}




\section{Wstęp}

Wraz z upływem czasu obserwuje się wzrost częstotliwości występowania zaburzeń słuchu na świecie. Według danych National Health and Nutrition Examination Survey w latach 1994-2006 częstość występowania zaburzeń słuchu u młodzieży i młodych dorosłych (w wieku 12-35 lat) zwiększyła się z 14,9\% do 19,5\%. W większości przypadków odnotowuje się niedosłuchy w zakresie wysokich częstotliwości (2-8 kHz). Zjawisko to jest związane między innymi $\mathrm{z}$ narażeniem na hałas $\mathrm{w}$ codziennym życiu czy długotrwałym słuchaniem głośnej muzyki przez słuchawki [1-3]. Według definicji przyjętej przez Światową Organizację Zdrowia niedosłuch można nazwać wykluczającym (ang. disabling hearing loss), czyli utrudniającym codzienne funkcjonowanie, wówczas, gdy mamy do czynienia $\mathrm{z}$ niedosłuchem w lepiej słyszącym uchu u osób dorosłych $>40 \mathrm{~dB}$ oraz u dzieci $>30 \mathrm{~dB}$ [1]. Obecnie szacuje się, że 360 mln ludzi na całym świecie, czyli 5,3\% populacji, cierpi z powodu niedosłuchu utrudniającego im codzienne funkcjonowanie, z czego $328 \mathrm{mln}$ (91\%) stanowią osoby dorosłe, natomiast pozostałe $32 \mathrm{mln}$ (9\%) - dzieci [1].

W zależności od rodzaju i stopnia niedosłuchu dzisiejsza medycyna proponuje pacjentom szereg różnych rozwiązań mających na celu poprawę słyszenia. Należą do nich: aparaty słuchowe, implanty ucha środkowego (ang. middle ear implant), urządzenia wszczepialne na przewodnictwo kostne (ang. bone conduction implant), systemy implantów ślimakowych (ang. cochlear implant, CI) czy implanty pniowe (ang. auditory brainstem implant, ABI) [4-6].

\section{Implanty ślimakowe i implanty pniowe}

System implantu ślimakowego jest to rodzaj elektronicznej protezy słuchowej, umożliwiającej percepcję dźwięku u osób z całkowitą lub częściową głuchotą [6]. Dzięki bezpośredniej stymulacji elektrycznej zakończeń nerwu słuchowego możliwe jest zastąpienie funkcji uszkodzonych komórek słuchowych ślimaka [6-8]. System ten składa się z dwóch części - wewnętrznej, umieszczanej operacyjnie w niszy kości skroniowej i przykrytej płatem skórnym, oraz zewnętrznej, noszonej za uchem. Część wewnętrzna składa się z: odbiornika i stymulatora elektrycznego, czyli tzw. kapsuły implantu, oraz elektrody wewnątrzślimakowej. Natomiast część zewnętrzną stanowi cyfrowy procesor mowy. Wszystkie powyżej wymienione części implantu zostały przedstawione na rycinie 1.

Zasada działania implantu ślimakowego jest następująca: mikrofon procesora mowy odbiera sygnał akustyczny, a następnie przekształca go w analogowy sygnał elektryczny, podawany na wejście przetwornika analogowo-cyfrowego, i zamienia go na sygnał cyfrowy, który z kolei zostaje odpowiednio przekształcony oraz zamieniony na bodziec elektryczny, a następnie za pośrednictwem fal radiowych przesłany przez transmiter do części wewnętrznej implantu. Umieszczona w ślimaku elektroda pozwala na zastąpieniu funkcji uszkodzonych komórek słuchowych i bezpośrednią elektryczną stymulację zakończeń nerwu słuchowego [6,7].

W implantach pniowych zasada działania jest zbliżona do działania systemu implantu ślimakowego, jednak oba

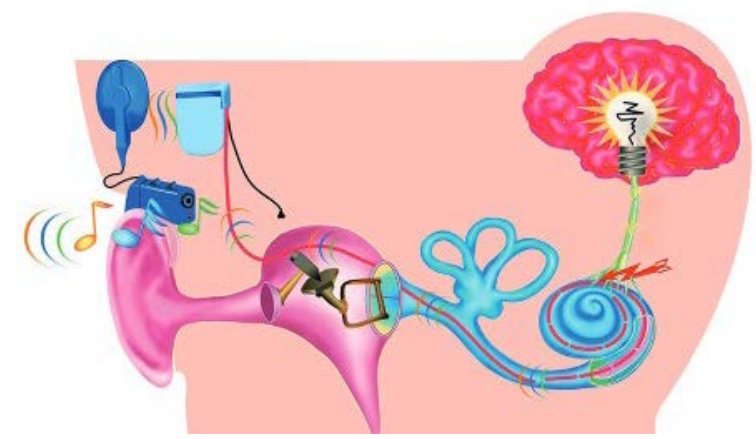

Rycina 1. Schemat budowy systemu implantu ślimakowego. Figure 1. Cochlear implant system.

systemy różnią się od siebie kształtem i miejscem ułożenia elektrody. W przypadku implantu pniowego poszczególne kontakty mają za zadanie stymulację jąder grzbietowych i brzusznych nerwu ślimakowego znajdujących się w pniu mózgu [6,9].

Obecnie system implantu ślimakowego jest uznawaną na całym świecie metodą leczenia zaburzeń słuchu u pacjentów ze znacznym i głębokim niedosłuchem odbiorczym. Według danych Agencji Żywności i Leków (ang. Food and Drug Administration, FDA) od grudnia 2012 roku ponad 324000 osób na całym świecie otrzymało implanty ślimakowe [8]. $\mathrm{W}$ grupie pacjentów $\mathrm{z}$ zaburzeniami słuchu znajdują się także osoby $z$ anomaliami w budowie ślimaka i nerwu słuchowego, czy osoby po usunięciu guza kąta mostowo-móżdżkowego, u których to $\mathrm{z}$ kolei skuteczną formą leczenia może być implant pniowy (ABI) [6,9].

\section{Hospitalizacje związane $z$ leczeniem zaburzeń słuchu za pomocą systemu implantu ślimakowego bądź implantu pniowego w Polsce}

W grudniu 2016 roku zostały opublikowane mapy potrzeb zdrowotnych (MPZ) w zakresie chorób nosa, zatok przynosowych, ucha, gardła i krtani w Polsce [10]. MPZ przygotowano odrębnie dla każdego $\mathrm{z}$ województw na podstawie danych za rok 2014. Zgodnie z rozporządzeniem Ministra Zdrowia mapy składają się z trzech części: 1) aspekty demograficzne i epidemiologiczne, 2) analiza stanu i wykorzystania zasobów oraz 3) prognozy.

$\mathrm{W}$ analizach wykorzystano dane jednostkowe o świadczeniach wykazanych przez świadczeniodawców do Narodowego Funduszu Zdrowia (NFZ). W opracowaniu zostały przedstawione informacje o hospitalizacjach, tj. o produktach z katalogu 1a i 1b. Dane te dotyczą świadczeń za 2014 rok, tj. hospitalizacji, które zakończyły się w 2014 roku.

Niniejsze opracowanie dotyczy hospitalizacji z rozpoznaniem H90 (według międzynarodowej klasyfikacji chorób ICD-10), czyli z powodu upośledzenia słuchu przewodzeniowego i czuciowo-nerwowego. W ramach hospitalizacji wykonano jedną z wymienionych poniżej procedur ICD-9:

- 20.96 - Wszczepienie/wymiana protezy ślimaka - nieokreślone inaczej,

- 20.97 - Wszczepienie/wymiana jednokanałowej protezy ślimaka, 


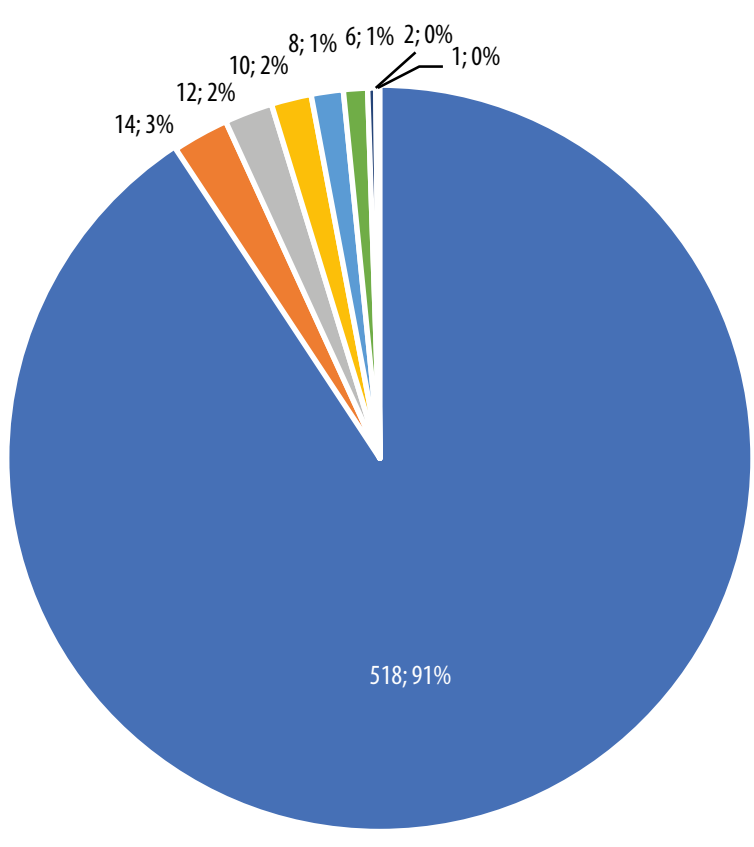

$\square \mathrm{h} 90.3 \square \mathrm{H} 90.0 \square \mathrm{H} 90.6 \square \mathrm{H} 90.5 \square \mathrm{H} 90.4 \square \mathrm{H} 90.8 \square \mathrm{H} 90 \approx \mathrm{H} 90.2$

Rycina 2. Struktura hospitalizacji w 2014 roku z uwzględnieniem głównej przyczyny [10].

Figure 2. Percentage of hospitalization in 2014 with divided to main causes [10].

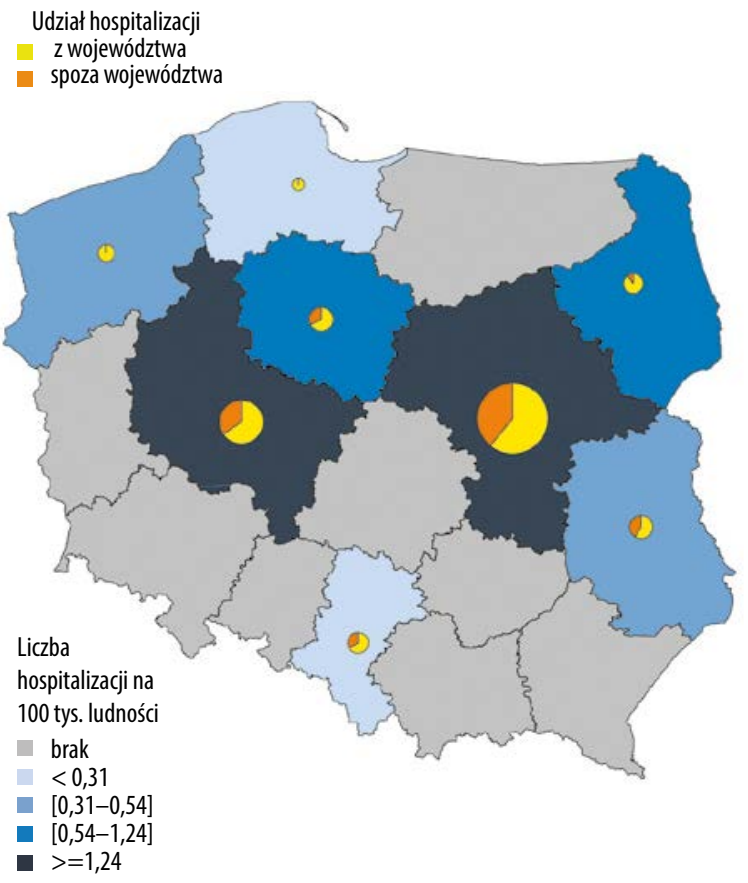

Rycina 4. Udział hospitalizacji pacjentów spoza województwa w 2014 roku [10].

Figure 4. Percentage of hospitalization from other voivodeship in 2014 [10].

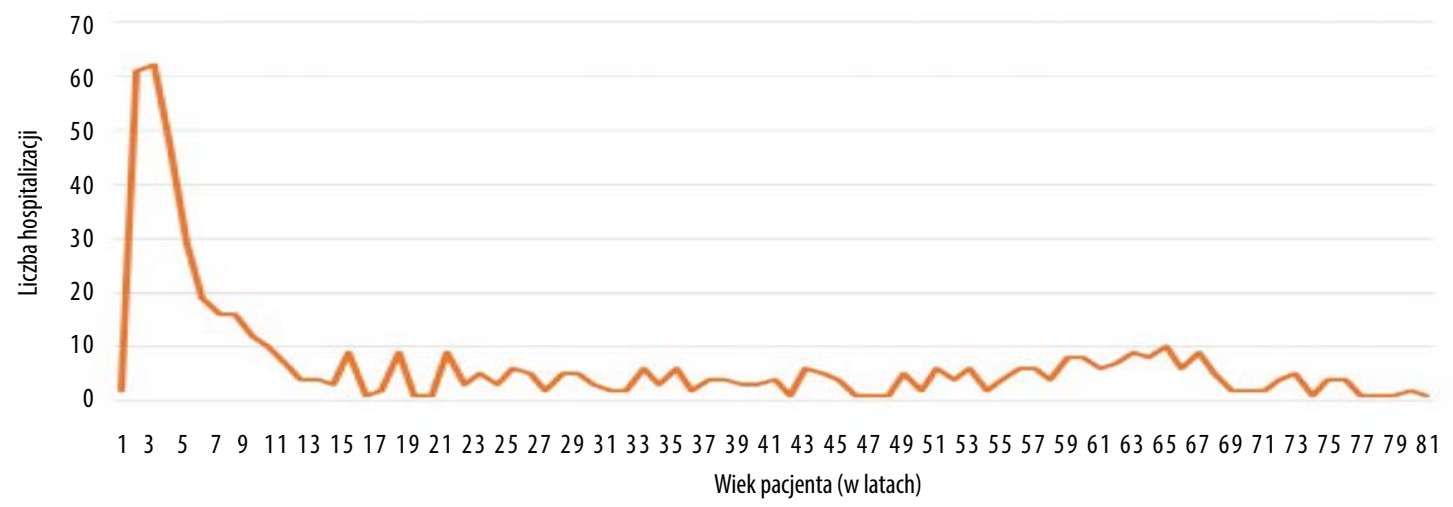

Rycina 3. Struktura hospitalizacji w 2014 roku z uwzględnieniem wieku pacjenta [10].

Figure 3. The number of hospitalizations in 2014, relative to the patient's age [10].

- 20.98 - Wszczepienie/wymiana wielokanałowej protezy ślimaka,

- 20.992 - Wszczepienie/wymiana implantu pniowego.

W 2014 roku sprawozdano 571 hospitalizacji z założonymi powyżej parametrami, a najczęstszym rozpoznaniem było H90.3, czyli głuchota czuciowo-nerwowa obustronna, która była przyczyną 518 hospitalizacji. Udział procentowy poszczególnych hospitalizacji z uwzględnieniem głównej przyczyny został przedstawiony na rycinie 2 .

Największa liczba hospitalizacji dotyczy dzieci w wieku 1-9 lat. Wiąże się to między innymi z odpowiednią profilaktyką, czyli prowadzeniem powszechnych badań przesiewowych słuchu u noworodków oraz dzieci w wieku szkolnym, dzięki czemu możliwe jest wczesne wykrycie zaburzeń słuchu, jak również podjęcie odpowiednich działań, mających na celu zminimalizowanie jego skutków. Kolejną grupą wiekową, u której można zaobserwować wzrost liczby hospitalizacji, są pacjenci w wieku $\geq 60$ lat, u których wraz $\mathrm{z}$ wiekiem dochodzi do podwyższenia progu słyszenia, czy to w wyniku presbyacusis, czy oddziaływania czynników środowiskowych, tj. leków ototoksycznych, hałasu, otosklerozy itp. Na rycinie 3 . przedstawiono strukturę hospitalizacji w 2014 roku według wieku pacjentów (odnoszącą się do rocznika urodzenia).

Wśród województw, w których wykonano najwięcej hospitalizacji w roku 2014, znajdują się województwa: mazowieckie, wielkopolskie oraz kujawsko-pomorskie (rycina 4). W przypadku województwa mazowieckiego w 2014 roku sprawozdano 430 hospitalizacji, z czego hospitalizacje dzieci stanowiły $56 \%$, hospitalizacje pacjentów spoza województwa mazowieckiego - 64\%; średni wiek osób dorosłych 
Tabela 1. Zestawienie sprawozdanych w 2014 roku hospitalizacji z uwzględnieniem liczby, odsetka hospitalizacji dziecięcych, odsetka hospitalizacji spoza województwa, średniego wieku pacjentów oraz średniej długości hospitalizacji [10].

Table 1. Juxtaposition of hospitalization reported in 2014 with number and percentage of pediatric hospitalization, percentage of hospitalization from other voivodeship, mean age of patients and mean length of hospitalization [10].

\begin{tabular}{|c|c|c|c|c|c|c|c|c|c|}
\hline Województwo & 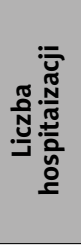 &  & 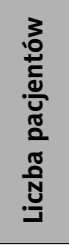 & 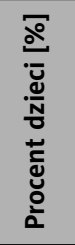 & 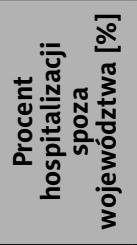 & 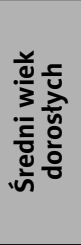 & 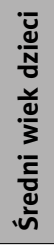 & 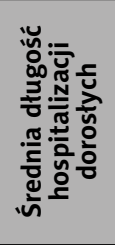 & 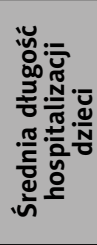 \\
\hline Kujawsko-pomorskie & 13 & 92,3 & 13 & 92,3 & 46,2 & 18 & 4 & 4 & 5 \\
\hline Lubelskie & 10 & 30,0 & 9 & 22,2 & 70,0 & 54 & 8 & 4 & 4 \\
\hline Mazowieckie & 430 & 56,5 & 427 & 56,2 & 64,2 & 48 & 4 & 5 & 4 \\
\hline Podlaskie & 9 & - & 9 & - & 11,1 & 60 & - & 5 & - \\
\hline Pomorskie & 2 & - & 2 & - & 0,0 & 70 & - & 4 & - \\
\hline Śląskie & 8 & - & 8 & - & 50,0 & 46 & - & 4 & - \\
\hline Wielkopolskie & 93 & 47,3 & 93 & 47,3 & 52,7 & 51 & 4 & 6 & 4 \\
\hline Zachodniopomorskie & 6 & 50,0 & 6 & 50,0 & 0,0 & 52 & 4 & 6 & 4 \\
\hline
\end{tabular}

Tabela 2. Zestawienie świadczeniodawców, którzy sprawozdali hospitalizacje z analizowanego zakresu w 2014 roku [10].

Table 2. List of service providers who reported hospitalizations from the analyzed scope in 2014 [10].

\begin{tabular}{|c|c|c|c|c|c|c|}
\hline Nazwa świadczeniodawcy & Województwo & : & 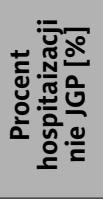 & 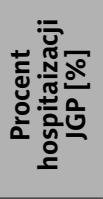 & 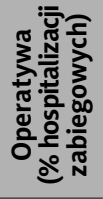 & 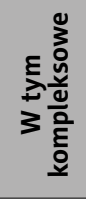 \\
\hline Instytut Fizjologii i Patologii Słuchu & Mazowieckie & 385 & 0,0 & 100,0 & 100,0 & 100,0 \\
\hline $\begin{array}{l}\text { Szpital Kliniczny im. H. Święcickiego Uniwersytetu Medycznego } \\
\text { im. K. Marcinkowskiego w Poznaniu }\end{array}$ & Wielkopolskie & 93 & 0,0 & 100,0 & 100,0 & 100,0 \\
\hline Samodzielny Publiczny Centralny Szpital Kliniczny & Mazowieckie & 45 & 0,0 & 100,0 & 100,0 & 100,0 \\
\hline Wojewódzki Szpital Dziecięcy im. J. Brudzińskiego w Bydgoszczy & Kujawsko-pomorskie & 13 & 7,7 & 92,3 & 92,3 & 92,3 \\
\hline Samodzielny Publiczny Szpital Kliniczny nr 4 w Lublinie & Lubelskie & 10 & 0,0 & 100,0 & 100,0 & 100,0 \\
\hline Uniwersytecki Szpital Kliniczny w Białymstoku & Podlaskie & 9 & 0,0 & 100,0 & 100,0 & 100,0 \\
\hline $\begin{array}{l}\text { Śamodzielny Publiczny Szpital Kliniczny im. A. Mielęckiego } \\
\text { Śląskiego Uniwersytetu Medycznego w Katowicach }\end{array}$ & Śląskie & 8 & 0,0 & 100,0 & 100,0 & 100,0 \\
\hline $\begin{array}{l}\text { Samodzielny Publiczny Szpital Kliniczny nr } 1 \\
\text { im. Prof. T. Sokołowskiego PUM }\end{array}$ & Zachodniopomorskie & 6 & 0,0 & 100,0 & 100,0 & 100,0 \\
\hline Uniwersyteckie Centrum Kliniczne & Pomorskie & 2 & 0,0 & 100,0 & 100,0 & 100,0 \\
\hline
\end{tabular}

JGP - jednorodne grupy pacjentów.

skierowanych na hospitalizację wynosił 48 lat, a dzieci - 4 lata. W województwie wielkopolskim w 2014 roku odnotowano 93 hospitalizacje, $\mathrm{z}$ czego hospitalizacje dzieci stanowiły $47 \%$, a osób spoza województwa wielkopolskiego - blisko 53\%; średni wiek pacjentów dorosłych i dzieci był zbliżony do podanego dla województwa mazowieckiego i wynosił odpowiednio 51 lat i 4 lata. Natomiast w województwie kujawsko-pomorskim w 2014 roku przeprowadzono 13 hospitalizacji, z czego hospitalizacje dzieci stanowiły $92 \%$, a osób spoza województwa - 46\%; średni wiek dorosłych wynosił 18 lat, a dzieci - 4 lata. Długość hospitalizacji była podobna we wszystkich województwach i wynosiła 4-6 dni. Powyższe dane zostały przedstawione na rycinie 5. oraz w tabeli 1 .

Tabela 2. przedstawia liczbę sprawozdanych w 2014 roku hospitalizacji z powodu leczenia zaburzeń słuchu przy



Rycina 5. Hospitalizacje pacjentów (dzieci i dorosłych) z 2014 roku leczonych przy użyciu systemu implantu ślimakowego, z uwzględnieniem czasu trwania hospitalizacji [10].

Figure 5. Hospitalizations of patients (children and adults) from 2014 treated with the cochlear implant system with duration of those hospitalizations [10]. 
użyciu systemu implantu ślimakowego. Wśród ośrodków, które sprawozdały najwięcej hospitalizacji z analizowanego zakresu w roku 2014, znajdują się: Instytut Fizjologii i Patologii Słuchu (385), Szpital Kliniczny im. H. Święcickiego Uniwersytetu Medycznego w Poznaniu (93) oraz Samodzielny Publiczny Centralny Szpital Kliniczny w Warszawie (45).

\section{Dyskusja}

Początkowo do operacji wszczepienia implantu ślimakowego kwalifikowani byli tylko pacjenci dorośli z całkowitą głuchotą, u których nie uzyskano poprawy w zakresie rozumienia mowy po zastosowaniu aparatów słuchowych. Wówczas stosowane były systemy jednokanałowe, umożliwiające jedynie odbiór podstawowych wrażeń słuchowych. Wraz z pojawieniem się systemów wielokanałowych kryteria kwalifikacji do operacji wszczepienia implantu poszerzyły się i rozpoczęto wszczepianie implantów dzieciom z wrodzonym głębokim niedosłuchem [7,10-13].

W Polsce pierwszej operacji wszczepienia implantu dokonał w 1992 roku prof. Henryk Skarżyński, z kolei w roku 2002 w Instytucie Fizjologii i Patologii Słuchu (IFPS) zainicjował on program leczenia częściowej głuchoty z zastosowaniem implantów ślimakowych [13]. Obecnie rozwiązanie to jest stosowane w wielu ośrodkach w Polsce, jednak IFPS znajduje się w czołówce placówek pod względem liczby hospitalizacji związanych z procedurą wszczepienia systemu implantu ślimakowego nie tylko w Polsce, lecz także na świecie - 385 hospitalizacji w 2014 roku [13,14].

Rozwój technologii oraz udokumentowana w licznych pracach skuteczność zastosowania systemu implantu ślimakowego jako metody leczenia zaburzeń słuchu spowodowały dalsze rozszerzanie kryteriów kwalifikacji. Kolejną grupę stanowią pacjenci z częściową głuchotą (ang. partial deafness), u których wyniki audiometrii tonalnej wykazują normę słuchową lub niewielkie obniżenie progu słyszenia $(125 \mathrm{~Hz}-1,5 \mathrm{kHz})$, oraz znacznym bądź głębokim ubytkiem słuchu w zakresie częstotliwości średnich i wysokich $(2-8 \mathrm{kHz})[7,13,14]$. Obecnie zastosowanie atraumatycznych elektrod oraz nowych technik chirurgicznych umożliwia zachowanie resztek słuchowych pacjenta, a co więcej - połączenie jego naturalnego słuchu ze słuchem elektrycznym poprzez jednoczasową stymulacje elektryczno-akustyczną [13]. Według koncepcji H. Skarżyńskiego, dotyczącej leczenia częściowej głuchoty w zależności od stopnia zachowania resztek słuchowych (potwierdzonych wynikiem audiometrii tonalnej), pacjenta można zakwalifikować do jednej z 4 grup: PDT-EC, PDT-EAS, PDT-ENS, PDT-ES [13-16].

Obecnie wśród użytkowników implantów ślimakowych są także osoby korzystające $\mathrm{z}$ systemów implantów obuusznie, pacjenci z jednostronną głuchotą (ang. single sided deafness) lub asymetrycznym niedosłuchem (ang. asymetric hearing loss) [17-19]. Dodatkową motywacją do podjęcia decyzji o poddaniu się operacji wszczepienia implantu ślimakowego są towarzyszące zaburzeniom słuchu uporczywe szumy uszne. Według doniesień literaturowych zastosowanie systemu implantu ślimakowego może przyczynić się do zmniejszenia intensywności szumów usznych, a niekiedy doprowadzić nawet do ich zaniku [18].
Wraz z rosnącą liczbą użytkowników systemów implantów słuchowych na świecie pojawiła się potrzeba sporządzenia pewnych regulacji odnośnie opieki nad pacjentami z zaburzeniami słuchu. Odpowiedzią na te potrzeby było utworzenie grupy HEARRING, zrzeszającej wiodące międzynarodowe ośrodki oferujące wszechstronne rozwiązania z zakresu zastosowania implantów słuchowych w leczeniu wad słuchu [20-23]. Sieć HEARRING zorganizowano w przekonaniu, że choć poszczególne ośrodki działające indywidualnie wnoszą pewien wkład w rozwój dziedziny implantów narządu słuchu, to połączenie zdobytej wiedzy i doświadczenia oraz dzielenie się informacjami w ramach globalnej sieci ośrodków może przynieść znacznie więcej korzyści dla pacjentów. Wspólnym celem członków grupy jest osiąganie postępów w leczeniu, poprawa jakości opieki i rozwój stosowanych w praktyce technik chirurgicznych, jak również rozpowszechnianie informacji $\mathrm{z}$ tych dziedzin za pośrednictwem wysokiej jakości szkoleń i inicjatyw edukacyjnych. Dzięki tym przedsięwzięciom sieć HEARRING realizuje swój zasadniczy cel, jakim jest zapewnienie jak największych korzyści pacjentom $\mathrm{z}$ niedosłuchem.

Na podstawie tych założeń grupa złożona $\mathrm{z}$ konsultanta krajowego w dziedzinie otorynolaryngologii oraz członków Towarzystwa Otorynolaryngologów, Foniatrów i Audiologów Polskich, a także Polskiego Towarzystwa Otolaryngologów Dziecięcych opracowała „Standardy jakości stosowania implantów ślimakowych u niemowląt, dzieci i młodzieży" [20]. Zgodnie z nimi zespół sprawujący opiekę nad pacjentem pediatrycznym powinien składać się z: co najmniej dwóch doświadczonych chirurgów otorynolaryngologów oraz anestezjologa dziecięcego, a po operacji - audiologa, psychologa, surdologopedy, inżynierów klinicznych i surdopedagoga. Wszystkie te osoby powinny mieć przeszkolenie $\mathrm{w}$ doborze aparatów słuchowych $\mathrm{u}$ pacjentów pediatrycznych $\mathrm{z}$ niedosłuchem od znacznego do głębokiego, doświadczenie w tym zakresie oraz wiedzę na temat implantów ślimakowych, procesu ich dopasowania oraz rehabilitacji słuchu i mowy [20]. Dodatkowo, jeżeli w skład zespołu podstawowego nie wchodzą specjaliści w dziedzinie: leczenia szumów usznych, leczenia zaburzeń równowagi, radiologii, fizyki medycznej, poradnictwa genetycznego, psychologii, psychiatrii, pediatrii, pedagogiki, tłumaczenia $\mathrm{z}$ języka migowego, pomocy społecznej dla osób niesłyszących i niedosłyszących, pomocy prawnej dla osób niesłyszących i niedosłyszących, należy zapewnić pacjentom do nich dostęp , gdyby zaistniała taka potrzeba. Specjaliści ci także powinni być odpowiednio wyszkoleni i mieć doświadczenie. Kluczową rolę w procesie rehabilitacji odgrywają rodzice, dlatego współpraca pomiędzy nimi a członkami zespołu jest konieczna, by zapewnić prawidłową stymulację rozwoju dziecka $\mathrm{z}$ niedosłuchem [20].

Ocena kliniczna kandydata do wszczepienia implantu ślimakowego opiera się na wywiadzie lekarskim, z uwzględnieniem szczegółowego wywiadu audiologicznego, oraz na wynikach specjalistycznych badań otolaryngologicznych. Przyszły użytkownik implantu zostaje poddany także ocenie logopedycznej, obejmującej określenie poziomu funkcjonowania językowego oraz percepcji słuchowej w oparciu o aparaty słuchowe. Dodatkowo w procedurze przewidziana jest także ocena psychologiczna, konsultacja 
okulistyczna, neurologiczna, kardiologiczna oraz genetyczna $[6,20,24]$. Zadaniem osób biorących udział w diagnostyce przedoperacyjnej powinno być wspomaganie rozwoju pacjenta, zwłaszcza w przypadku dzieci, a także udzielenie mu profesjonalnej pomocy.

Drugi etap stanowi zabieg wszczepienia implantu, czyli postępowanie śródoperacyjne obejmujące wprowadzenie wiązki elektrod do ślimaka oraz umieszczenie kapsuły implantu na kości skroniowej pacjenta. Trzeci etap stanowi opieka pooperacyjna, czyli szeroko pojęta rehabilitacja medyczna, uwzględniająca rehabilitację logopedyczną oraz proces dopasowania protezy słuchowej.

Na skuteczność procesu dopasowania systemu implantu ślimakowego ma wpływ wiele czynników, takich jak: przyczyna niedosłuchu, wiek pacjenta, czy czas, który upłynął od momentu utraty słuchu do operacji wszczepienia implantu. Ważną rolę odgrywają również właściwości biofizyczne złącza elektroda - komórki nerwowe, które zależne są od:

- anatomicznej budowy ślimaka (jego wymiaru i kształtu),

- elektrycznych właściwości tkanek,

- budowy wiązki elektrod (wymiarów, kształtu kontaktów elektrycznych oraz długości wiązki),

- ilości przetrwałych włókien nerwowych,

- wzajemnego położenia włókien i kontaktów elektrod [6,7].

Wymienione powyżej właściwości mają wpływ na późniejsze korzyści słuchowe osiągane przez użytkowników implantów.

Podczas dopasowania systemów implantów rutynowo wykonuje się badania mające na celu sprawdzenie poprawności działania systemu, np. pomiar impedancji elektrycznej elektrod. Dodatkowo wykonywane są tzw. badania subiektywne, wymagające współpracy pacjenta - audiometria progowa w polu swobodnym i audiometria słowna w polu swobodnym. Uzupełnieniem procedury są badania obiektywne - pomiary biofizyczne. Zaletą obiektywnych metod diagnostycznych jest to, że nie wymagają udziału pacjenta, dlatego mogą być $z$ powodzeniem wykorzystywane u małych dzieci lub osób z niepełnosprawnością intelektualną [25]. Przykładem takich badań są: pomiar elektrycznie wywołanych słuchowych odpowiedzi pnia mózgu (ang. electrically evoked auditory brainstem response, EABR), pomiar elektrycznie wywołanego odruchu z mięśnia strzemiączkowego (ang. electrically evoked stapedius responses thresholds, ESRT) czy pomiar elektrycznie wywołanego potencjału czynnościowy nerwu słuchowego (ang. electrically evoked compound action potential of the auditory nerve, ECAP) [25].

Coraz więcej autorów, którzy zajmują się zagadnieniem dopasowania systemu implantu, przekonuje, iż powinno być ono rozumiane całościowo - jako postępowanie ukierunkowane na rozwiązanie problemu, mające na celu ograniczenie negatywnych skutków niepełnosprawności słuchowej. Takie podejście jest zgodne $\mathrm{z}$ tzw. funkcjonalnym modelem niepełnosprawności, stworzonym na potrzeby Międzynarodowej Klasyfikacji Funkcjonowania, Niepełnosprawności i Zdrowia (ICF) [7,26,27]. Według ICF „uszkodzenie" rozumiane jest jako problem w funkcjonowaniu bądź strukturze ciała, natomiast „ograniczenie aktywności” polega na trudnościach związanych z zaangażowaniem się jednostki w określone sytuacje życiowe. W związku z powyższym proces dopasowania systemu implantu ślimakowego powinien być rozumiany jako działania mające na celu stworzenie warunków do aktywności i przywrócenie pacjenta do pełnego uczestnictwa w sytuacjach życiowych $[26,27]$.

\section{Wnioski}

1. Wraz z upływem czasu oraz poszerzającymi się kryteriami kwalifikacyjnymi do operacji wszczepienia implantu wzrasta także liczba hospitalizacji związanych z leczeniem zaburzeń słuchu przy użyciu implantów ślimakowych bądź pniowych, a co za tym idzie - zwiększa się także zapotrzebowanie na opiekę pooperacyjną.

2. Instytut Fizjologii i Patologii Słuchu w Kajetanach znajduje się na pierwszym miejscu w Polsce pod względem sprawozdanych hospitalizacji związanych z leczeniem zaburzeń słuchu przy użyciu systemów implantów ślimakowych bądź pniowych.

3. Najwięcej sprawozdanych hospitalizacji dotyczyło dzieci w wieku 1-9 lat, co jest wynikiem między innymi prowadzenia programów badań przesiewowych słuchu. Kolejną stosunkowo liczną grupę pacjentów stanowią pacjenci $\mathrm{w}$ wieku $\geq 60$ lat, u których wraz z wiekiem oraz oddziaływaniem czynników środowiskowych, np. leków ototoksycznych, hałasu, dochodzi do systematycznego pogarszania się słuchu.

4. W związku $\mathrm{z}$ rosnącą liczbą użytkowników implantów ślimakowych bądź pniowych wzrasta zapotrzebowanie na wymianę ich części zewnętrznych, czyli procesorów mowy, po upływie okresu gwarancji. Zasadnym wydaje się rozważenie zwiększenia funduszy przeznaczanych na ten cel. Pomogłoby to uniknąć generowania długich kolejek oraz skróciłoby czas oczekiwania na wymianę sprzętu. W chwili obecnej część pacjentów po upływie gwarancji pozostaje bez działającego procesora do momentu wymiany. W przypadku dzieci ma to ogromny wpływ na dalszy rozwój, natomiast u osób starszych może wpływać na ponowną utratę niezależności, jak również spowolnienie ich procesów poznawczych. Zaprzestanie noszenia procesora mowy implantu ślimakowego bądź pniowego może być jednoznaczne $\mathrm{z}$ utratą korzyści słuchowych uzyskanych dzięki rehabilitacji.

\section{Piśmiennictwo:}

1. WHO global estimates on prevalence of hearing loss. Mortality and Burden of Diseases and Prevention of Blindness and Deafness WHO, 2012; https://www.who.int/pbd/deafness/WHO_ GE_HL.pdf [dostęp: 20.05.2019].
2. Shargorodosky J, Curhan SG, Curhan GC, Eavey R. Change in prevalence of hearing loss in US adolescents. JAMA, 2010; 304(7): 772-78. 
3. Scientific Committee on Emerging and Newly Identified Health Risks SCENIHR. Potential health risks of exposure to noise from personal music players and mobile phones including a music playing function. Preliminary report; ec.europa.eu/health/ph_risk/committees/04_scenihr/docs/scenihr_o_017.pdf [dostęp: 20.05.2019].

4. Ratuszniak A, Mrówka M, Skarżyński P.H, Skarżyński H. Urządzenia wszczepialne na przewodnictwo kostne - zasada działania oraz wskazania. Now Audiofonol, 2017; 6(3): 29-34.

5. Olszewski Ł, Porowski M. Implanty ucha środkowego. W: Protetyka słuchowa. Chojan E. (red.). Poznań: Wydawnictwo Naukowe UAM; 2014, s. 729-49.

6. Skarżyński H, Piotrowska A, Lorens A. Wszczepy ślimakowe. W: Audiologia kliniczna. Śliwińska-Kowalska M. (red.). Łódź: Mediton; 2005, 429-42.

7. Pieczykolan A, Kruszyńska M, Wiśniewski T, Lorens A i wsp. Dopasowanie systemu implantu ślimakowego - podstawy teoretyczne. Now Audiofonol, 2016; 5(4): 24-35.

8. National Institute of Health (NIH). Fact Sheet: Cochlear Implants. NIH Publication No. 11-4798 (Updated March 2011); http://www.nidcd.nih.gov/health/hearing/pages/coch.aspx [dostęp: 21.05.2019].

9. Dos Santos Malerbi AF, Schmidt Gofii-Gomez MV, Koji Tsuji R i wsp. Auditory brainstem implant in postmeningitis totally ossified cochleae. Acta Otolaryngol, 2018; 138(8): 722-26.

10. Mapy potrzeb zdrowotnych dla Polski na dzień 10.12.2018; http:// www.mpz.mz.gov.pl/wp-content/uploads/sites/4/2018/01/polska-1.pdf [dostęp: 10.12.2018].

11. Chouard CH, MacLeod P. Implantation of multiple intracochlear electrodes for rehabilitation of total deafness: preliminary report. Laryngoscope, 1976; 86: 1743-51.

12. State of Western Australia - Department of Health. Clinical Guidelines for Adult Cochlear Implantation, 2011; http://www.healthnetworks.health.wa.gov.au/docs/1301_CG_AdultCochlearImplantation.pdf [dostęp: 2011]

13. Skarżyński H, Lorens A, Piotrowska A, Skarżyński PH. Hearing Preservation in Patrial Deafness Treatment. Med Sci Monit, 2010; 16(11): CR555-562.

14. Skarżński H, Lorens A, Skarżyński PH. Electro-Natural Stimulation (ENS) in Partial Deafness Treatment - a case study. J Hear Sci, 2014; 4(4): 67-71.

15. Skarżyński H, Matusiak M, Piotrowska A, Skarżyński PH. Surgical techniques in Partial Deafness Treatment. J Hear Sci, 2012; 2(3): 9-13.

16. Skarżyński H, Skarżyński PH. Nowa strategia leczenia częściowej głuchoty - 18 lat doświadczeń własnych. Now Audiofonol, 2014; 3(5): 9-16.
17. Pyschny V, Landwehr M, Hahn M, Lang-Roth R, Walger M, Meister $\mathrm{H}$. Head shadow, squelch, and summation effects with an energetic or informational masker in bilateral and bimodal CI users. J Speech Lang Hear Res, 2014; 57(5): 1942-60.

18. Häußler SM, Köpke V, Knopke S, Gräbel S, Olze H. Multifactorial positive influence of cochlear implantation on patients with single-sided deafness. Laryngoscope, 2019; https://onlinelibrary.wiley.com/doi/full/10.1002/lary.28007 [dostęp: 30.04.2019].

19. Skarżyński H, Lorens A, Kruszyńska M, Obrycka A, Pastuszak D, Skarżyński PH. The hearing benefit of cochlear implantation for individuals with unilateral hearing loss, but no tinnitus. Acta Otolarygol, 2017; 137(7): 723-29.

20. Skarżyński H, Mielnik-Niedzielska G, Kochanek K, Niedzielski A, Skarżyński PH, Lorens A. Standardy jakości stosowania implantów ślimakowych u niemowląt, dzieci i młodzieży. Stanowisko Towarzystwa Otorynolaryngologów, Foniatrów i Audiologów Polskich oraz Polskiego Towarzystwa Otolaryngologów Dziecięcych. Now Audiofonol, 2018; 7(1): 7-15.

21. Van de Heyning P, Adunka O, Atlas M, Baumgartner M i wsp. Standards of practice in the field of hearing implants. Cochlear Implants Int, 2013; 14(2): S1-5.

22. Hearring Group. Quality Standards for Cochlear Implantation in Adults and Older Adults, 2017; https://www.hearring.com/ wp-content/uploads/2018/11/hearring_ci_adult_quality_standards_rev2_2017.pdf [dostęp: 20.04.2019].

23. Hearring Group 2017. Quality Standards for Cochlear Implantation in Infants, Children, and Young Adults, 2017; https:// www.hearring.com/wp-content/uploads/2018/11/hearring_ci_ quality_standards_under_12_months_rev2_2017.pdf [dostęp: 20.04.2019].

24. Piotrowska A, Lorens A, Szuchnik J, Wojewódzka B, Kosmalowa J, Skarżyński H. Procedura przedoperacyjna kwalifikacji do wszczepienia implantu ślimakowego stosowana w Instytucie Fizjologii i Patologii Słuchu w Warszawie. Audiofonologia, 2001; 20: 43-50.

25. Lorens A, Piotrowska A, Wąsowski A, Walkowiak A, Skarżyński $\mathrm{H}$ i wsp. Objective method of paediatric cochlear implant system fitting. New Med, 2004; 4: 109-111.

26. Lorens A. Model rehabilitacji audiologicznej po wszczepieniu implantu ślimakowego opracowany na podstawie Międzynarodowej Klasyfikacji Funkcjonowania, Niepełnosprawności i Zdrowia (ICF). Now Audiofonol, 2014; 3(5): PK77-90.

27. Światowa Organizacja Zdrowia. Międzynarodowa Klasyfikacja Funkcjonowania, Niepełnosprawności i Zdrowia (ICF). Warszawa: Centrum Systemów Informacyjnych Ochrony Zdrowia; 2009. 